\title{
Occurrence of Multiple Antibiotic Resistant E. coli on Surface Water of River Ganga at Allahabad, Uttar Pradesh, India
}

\author{
Mitali Dhimann ${ }^{1}$, Mishra SS ${ }^{2 *}$, Tripathy $\mathrm{RC}^{3}$ and Dwivedi BK ${ }^{1}$ \\ ${ }^{1}$ Department of Biological Sciences, Mahatma Gandhi Chitrakoot Gramodaya Vishwavidyalaya, India \\ ${ }^{2}$ ICAR-Central Institute of Freshwater Aquaculture, India \\ ${ }^{3}$ Bioved Research Society, India
}

Submission: January 13, 2018; Published: July 17, 2018

Corresponding author: Mishra SS, ICAR-Central Institute of Freshwater Aquaculture, Kausalyaganga, Bhubaneswar - 751002, Odisha, India; Tel: +91-9433188172; Email: ss_mishra60@yahoo.co.uk

Keywords: MAR; Multiple antibiotic resistance; River ganga; E. coli; Microbial load

\section{Introduction}

Rivers Ganga, the largest river system in India, receive millions of litres of sewage, industrial and agricultural wastes, leading to serious water quality and health problems in the towns and villages using these rivers or wetlands as a source of water [1]. The discharge of wastes from municipal sewers is one of the most important water quality issues worldwide. Municipal sewage contains human faeces and water contaminated with these effluents may contain pathogenic organisms and, consequently, cause disease in humans and animals. Because antibiotics are widely used in the aquaculture and food industry, leading to contamination of water resources, thus many of these bacteria are getting genetically changed and becoming resistant to different antibiotics, raising an alarm for human health [2,3]. Antimicrobial resistance is a public health threat and characteristic of pathogens causing different diseases. World Health Organization statistics indicate that half of India's morbidity is water related. Increased resistance to antibiotics may pose a challenge for the effective treatment of bacterial infections [4]. According to the WHO, waterborne diseases account for 5 million deaths annually, worldwide [5]. Many pathogenic bacteria like Vibrio species, Aeromonas, E. coli, Salmonella, Shigella, Listeria etc. have been isolates and identified from aquatic systems, which pose serious threat to human and animal lives $[2,6,7]$. River Ganga at Allahabad zone is of religious importance and lakhs of people from different parts of the country gather here on several occasions of Hindu festivals to take bath in this holy river. To understand the quality river
Ganga at Allahabad zone, water quality was assessed in terms of physicochemical parameters, microbial load and presence of antibiotic resistant microbes.

\section{Materials and Methods \\ Collection of water samples and analysis}

Water samples were collected from river Ganga at six different sampling sites at Allahabad zone viz. Sringverpur ghat, Rasulabad ghat, Sangam, Chatnag ghat, Manaiya ghat and Sirsha ghat. On different occasions, the water samples two litre each, were collected in triplicate, between 7:00 A.M. and 10 A.M. in plastic bottles for physicochemical analysis and in sterile polyethylene bottles for microbial analysis. Selective variables, e.g., DO (\% saturation), $\mathrm{pH}$, conductivity and turbidity were estimated using Eutech CyberScan PCD650 (Thermo Scientific) Multiple parameter system with submersible probes was used and the data were noted at the spot. Other water quality parameters were estimated following APHA [8]. The microbiological load in terms of fecal coliforms and E. coli were estimated using standard procedures [9].

\section{Antibiotic sensitivity test for selected microbes}

Antibiotic susceptibility and resistance pattern was determined by the single disk diffusion method of Bauer et al. [10] using Mueller-Hinton agar or Antibiotic assay medium No.37 (HiMedia, Mumbai). Selected 120 E.coli isolates were tested for their antibiotic sensitivity and resistance pattern to 12 different antibiotics. The plates were inoculated with 
overnight bacterial cultures, $100 \mu$ bacterial culture $\operatorname{COD}_{660}=$ 1) using a swab. Different antibiotic discs containing different concentration of antibiotics were then placed on the agar plates and incubated at $37{ }^{\circ} \mathrm{C}$ for $24-48 \mathrm{~h}$. The zone of inhibition was noted at the end of incubation period and the antibiotics were represented as either sensitive or resistant or intermediate.

MAR indices for each isolate were then calculated by dividing the number of antibiotics to which the isolate was resistant by the total number of antibiotics tested, on the lines of Vivekanandhan et al. [11] and Watkinson et al. [12]. The MAR index when applied to a single isolate is defined as $a / b$, where ' $a$ ' represents the number of antibiotics to which the isolate was resistant and 'b' represents the number of antibiotics to which the isolate was exposed. MAR index value higher than 0.2 is considered to have originated from high-risk sources of contamination like human, commercial poultry farms, swine and dairy cattle where antibiotics are very often used. MAR index value of less than or equal to 0.2 considered as the origination of strain from animals in which antibiotics are seldom or never used [13].

\section{Results and Discussion}

Freshwater bodies polluted by faecal discharges from man, pets, farm animals and wild animals may transport a variety of pathogens such as bacteria (Shigella, Salmonella, Cholera vibrio, Escherichia), viruses and protozoans. Wide use of antibiotics to treat bacterial infections and incorporation of sub-therapeutic dose of antibiotics into feeds for cultured organism resulted in a global increase in antibiotic resistance among pathogenic bacteria. The problem is more serious in developing countries, where antibiotics are used widely. In India, antibiotics are extensively applied in animal husbandry and aquaculture [11]. The medical community has been witnessing a growing epidemic of infections due to multiple antibiotic resistant (MAR) Gram-negative bacteria involving almost whole globe. MAR bacteria, thus, refers to those which are resistant to a vast range of antibiotics [14]. According to the WHO, waterborne diseases account for 5 million deaths annually, worldwide [5]. Many pathogenic bacteria like Vibrio species, Aeromonas, E.coli, Salmonella, Shigella, listeria etc. have been isolates and identified from aquatic systems, which pose serious threat to human and animal lives $[2,6,7]$.

In the present study, water samples were collected from six sampling sites on river Ganga in different seasons (Summer, Winter and Rainy season) for three years. The physicochemical parameters and microbiological load at different sampling stations have been presented in Table 1. TDS values were in the range of 201-384NTU with higher values were observed at Sangam, which is considered important religious place of bathing by pilgrims. However maximum BOD5 values were observed at Chatnag ghat due to high organic load at the site (Table 1). Similarly, the total Fecal coliforms (E. coli) were significantly higher than permissible limit in all sampling stations, indicating these sites are polluted and water at these sites were not suitable for drinking and bathing. Selected 128 fecal coli (E. coli) isolates were tested for their antibiotic sensitivity against 12 different antibiotics and the antibiotic susceptibility-resistance (AMR) pattern have been presented in Table 2. Results indicated out of 128 isolates screened 120 were resistant to Ampicillin, 122 isolates to Kanamycin, 92 isolates to Streptomycin and 112 isolates to Teracycline. However, most isolates were observed to be sensitive to antibiotics like Gentamycin, Chloramphenicol, Ciprofloxacin, Norfloxacin and Ofloxacin, which are commonly used in human and animal health care. However, all isolates were observed to be resistant to Penicillin G.

Table 1:Physicochemical and microbiological quality of water samples collected from different sampling stations in river Ganga at Allahabad Zone during different seasons.

\begin{tabular}{|c|c|c|c|c|c|c|c|}
\hline \multirow{2}{*}{ Parameters } & \multirow{2}{*}{ Sampling Season } & \multicolumn{6}{|c|}{ Sampling Stations on River Ganga at Allahabad Zone } \\
\hline & & SringverpurGhat & RasulabadGhat & Sangam & Chatnag & Manaiya & SirshaGhat \\
\hline \multirow{3}{*}{$\mathrm{pH}$} & Summer & 8.65 & 8.45 & 8.49 & 8.85 & 8.14 & 8.23 \\
\hline & Post-Monsoon & 9.13 & 8.42 & 8.26 & 8.42 & 8.11 & 8.53 \\
\hline & Winter & 8.8 & 9.1 & 8.1 & 8.75 & 8.28 & 8.34 \\
\hline \multirow{3}{*}{ WT $\left({ }^{\circ} \mathrm{C}\right)$} & Summer & 26.8 & 27.3 & 25.9 & 28.2 & 26.3 & 27.3 \\
\hline & Post-Monsoon & 28.3 & 31 & 29.5 & 31.2 & 29.2 & 30 \\
\hline & Winter & 16.5 & 18.3 & 17.1 & 18.4 & 17.6 & 19 \\
\hline \multirow{3}{*}{$\begin{array}{l}\text { Turbidity } \\
\text { (NTU) }\end{array}$} & Summer & 12.5 & 13.2 & 8.8 & 9.3 & 6.4 & 7.3 \\
\hline & Post-Monsoon & 12.5 & 18.2 & 12.8 & 11.3 & 10.4 & 10.3 \\
\hline & Winter & 7.5 & 8.2 & 3.6 & 6.2 & 4.4 & 3.7 \\
\hline \multirow{3}{*}{ TDS (ppm) } & Summer & 201 & 214 & 384 & 318 & 329 & 236 \\
\hline & Post-Monsoon & 232.5 & 185.5 & 205.5 & 177.5 & 219.3 & 204.5 \\
\hline & Winter & 232.2 & 232.5 & 357.5 & 246.2 & 331.5 & 203.5 \\
\hline DO (ppm) & Summer & 8.24 & 8.36 & 10.21 & 8.84 & 9.36 & 7.36 \\
\hline
\end{tabular}




\section{Oceanography \& Fisheries Open access Journal}

\begin{tabular}{|c|c|c|c|c|c|c|c|}
\hline & Post-Monsoon & 12.2 & 10.72 & 5.66 & 11.08 & 8.16 & 10.08 \\
\hline & Winter & 10.73 & 12.5 & 8.64 & 11.05 & 8.8 & 9.76 \\
\hline \multirow{3}{*}{$\begin{array}{l}\text { T.Alkalinity } \\
\text { (ppm) }\end{array}$} & Summer & 109 & 122 & 134 & 146 & 152 & 148 \\
\hline & Post-Monsoon & 183 & 168 & 128 & 131 & 118 & 126 \\
\hline & Winter & 178 & 184 & 206 & 188 & 214 & 152 \\
\hline \multirow{3}{*}{$\begin{array}{l}\text { T.Hardness } \\
(\mathrm{ppm})\end{array}$} & Summer & 152 & 208 & 243 & 311 & 283 & 194 \\
\hline & Post-Monsoon & 248 & 224 & 216 & 219 & 246 & 108 \\
\hline & Winter & 221 & 252 & 302 & 251 & 223 & 271 \\
\hline \multirow{3}{*}{ BOD5 (ppm) } & Summer & 6.8 & 8.8 & 7.6 & 9 & 6.8 & 5.8 \\
\hline & Post-Monsoon & 5.2 & 4.5 & 5.3 & 6.7 & 4.5 & 4.8 \\
\hline & Winter & 6.5 & 6.8 & 7.9 & 10.7 & 4.5 & 4.8 \\
\hline \multirow{3}{*}{$\begin{array}{c}\text { FC (cfu/ } \\
100 \mathrm{ml})\end{array}$} & Summer & $2.5 \times 105$ & $1.7 \times 105$ & $2.1 \times 104$ & $2.8 \times 105$ & $6.2 \times 106$ & $7.1 \times 105$ \\
\hline & Post-Monsoon & $1.8 \times 104$ & $3.7 \times 103$ & $2.1 \times 103$ & $3.2 \times 105$ & $2.2 \times 104$ & $4.1 \times 104$ \\
\hline & Winter & $2.1 \times 102$ & $7.2 \times 103$ & $5.5 \times 105$ & $6.2 \times 105$ & $7.2 \times 104$ & $3.1 \times 104$ \\
\hline
\end{tabular}

*Each data represents average value of six readings.

WT: Water Temperature, EC: Electrical conductivity, TDS: Total dissolved solids, BOD5: 5-day Biological Oxygen Demand, Hardness: Total hardness, T Alkalinity: Total Alkalinity, FC: Fecal coli in cfu/100ml, cfu: Colony forming unit.

Table 2: Antibiogram of E. coli (Fecal coliforms) isolated from surface water of river Ganga at Allahabad zone, Uttar Pradesh, India.

\begin{tabular}{|c|c|c|c|}
\hline \multicolumn{2}{|c|}{ Antibacterial Agent with Concentration of Antibiotic } & \multicolumn{2}{|c|}{ Number of Isolates $(n=128)$; Percentages in Parenthesis } \\
\hline & Resistant & Intermediate & Susceptible \\
\hline Ampicillin (A) $(10 \mu \mathrm{g})$ & $120(94 \%)$ & $6(4.7 \%)$ & $2(1.6 \%)$ \\
\hline Penicillin G (P) (10 Units) & $128(100 \%)$ & $0(0 \%)$ & $0(0 \%)$ \\
\hline Tetracycline (T) $(30 \mu \mathrm{g})$ & $112(87.5 \%)$ & $14(11 \%)$ & $2(1.6 \%)$ \\
\hline Gentamycin $(\mathrm{G})(10 \mu \mathrm{g})$ & $4(3.1 \%)$ & $23(18 \%)$ & $101(79 \%)$ \\
\hline 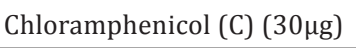 & $1(0.8 \%)$ & $12(9.4 \%)$ & $115(89.8 \%)$ \\
\hline Streptomycin (S) $(25 \mu \mathrm{g})$ & $92(72 \%)$ & $14(11 \%)$ & $22(17 \%)$ \\
\hline Ciprofloxacin (Cf) $(5 \mu \mathrm{g})$ & $4(3.1 \%)$ & $22(17.2 \%)$ & $102(79.7 \%)$ \\
\hline Norofloxacin (Nf) $(10 \mu \mathrm{g})$ & $6(4.7)$ & $18(14.1)$ & $104(81.2)$ \\
\hline Cephalothin (Ce) $(30 \mu g)$ & $24(18.8 \%)$ & $18(14.2 \%)$ & $86(67 \%)$ \\
\hline 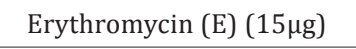 & $72(56.3)$ & $21(16.4)$ & $35(27.3)$ \\
\hline 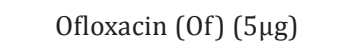 & $6(4.7)$ & $18(14.1)$ & $104(81.2)$ \\
\hline 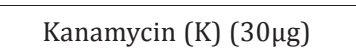 & $122(95.3)$ & $6(4.7)$ & $0(0 \%)$ \\
\hline
\end{tabular}

Antimicrobial resistance in E. coli has been reported worldwide and increasing rates of resistance among E. coli is a growing concern in both developed and developing countries [15]. Dhaka et al. [16] studied antibiogram profile of diarrhoeagenic Escherichia coli (DEC) pathotypes isolated from human, animal, foods and associated environmental sources in India. DEC isolates from human infants $(n=19)$ showed the highest resistance against ampicillin and cefotaxime each (94.7\%), followed by tetracycline (84.2\%), ceftriaxone (78.9\%), co-trimoxazole (73.7\%), and ciprofloxacin (68.4\%). Also, the DEC isolates from animals $(n=25)$, wherein the highest resistance was observed against ampicillin (96.0\%), followed by tetracycline $(88.0 \%)$, cefotaxime $(84.0 \%)$, co-trimoxazole (80.0\%), ceftriaxone (64.0\%), and ciprofloxacin (52.0\%). Radu et al. [17] investigated the prevalence and resistance to antibiotics for Aeromonas species from retail fish in Malaysia.
Reports have indicated that regular and continuous use of antibiotics in aquaculture has been one of the reasons responsible for increased incidence of antibiotic resistant bacteria in aquatic environments $[18,19]$. In their study Mishra et al. [20] studied antibiogram of Vibrios and Aeromonas spp. using a variety of commonly used antibiotics. The results indicated that most of the isolates were sensitive to chloramphenicol, ciprofloxacin, ofloxacin, norfloxacin and gentamycin, but resistant to ampicillin, oxytetracycline and erythromycin. Their results corroborate the observations on the antibiotic sensitivity of various Vibrio isolates [2,21]. Sasmal \& Abraham [21] noted high sensitivity of Aeromonas spp. and Pseudomonas spp. to broad spectrum antibiotics, except oxytetracycline and nitrofurantoin, where as Hameed \& Rao [22] observed higher sensitivity of $V$. campbellii-like bacterium from hatchery $P$. monodon larvae, to chloramphenicol and resistant to 11 other antimicrobials tested. 
The minimum inhibitory concentrations of chloramphenicol, oxytetracycline and tetracycline were recorded as 5, 150 and $200 \mathrm{ppm}$, respectively [19]. Emergence and spread of resistance to many of these antimicrobial agents is reducing their effectiveness [23]. Antimicrobial resistance (AMR) within a wide range of infectious agents is a growing public health threat of broad concern to countries and multiple sectors. Antimicrobial resistance (AMR) threatens the effective prevention and treatment of an ever-increasing range of infections caused by bacteria, parasites, viruses and fungi [4].

The MAR indices for each isolate were calculated in the present study by dividing the number of antibiotics to which the isolate was resistant by the total number of antibiotics tested. The MAR indices in the range of 0.26 to 0.67 was identified in this study indicating many isolates were resistant to multiple number of antibiotics. The higher MAR levels of isolates are most probably due to the larger range of drugs utilized in human, animal and aquaculture therapy and the potential exchange of resistance during the treatment process. WHO have indicated that the use of antibiotics in medicine and their applications in animal husbandry has brought about phenotypic changes, often due to chromosomal mutations, and antibiotic resistance in E. coli has been globally identified in isolates from environmental, animal and human sources [4]. Kinge et al. [24] reported that E. coli has been linked to well-known antibiotic-resistant gene pools and that these genes are transferred into the normal flora of humans and animals, where they exert a strong selective pressure for the emergence and spread of resistance in E. coli strains. In the present study, E. coli isolates from river Ganga were sensitive to Chloramphenicol, Ciprofloxacin, Ofloxacin, Norfloxacin and Gentamycin, but resistant to ampicillin, Tetracycline and Erythromycin. The results of present study corroborate the observations of others [2,21]. However, as a general guideline USFDA has banned use of such chemicals in aquaculture use due to their high health risks $[25,26]$. It has been observed that in some countries like in India, with no specific strict regulation governing the use of these chemotherapeutants in fish culture, such chemicals are being widely used in hatcheries and culture ponds and tanks [22]. Considering the potential hazards of antibiotics responsible for development of antibiotic resistant bacteria in aquatic ecosystem, use of alternative antibacterial chemicals like antiseptics and herbal medicines/preparations can be advocated for use in aquaculture operations for disease management.

\section{Conclusion}

Rivers Ganga, the largest river system in India, receive millions of litres of sewage, industrial and agricultural wastes, leading to serious water quality and health problems in the towns and villages using these rivers or wetlands as a source of water [1]. Many pathogenic bacteria like Vibrio species, Aeromonas, E. coli, Salmonella, Shigella, Listeria etc. have been isolates and identified from aquatic systems, which pose serious threat to human and animal lives. In the present study water quality of river Ganga at Allahabad zone was assessed in terms of physicochemical parameters, microbial load and presence of antibiotic resistant microbes. Significantly higher level of total Fecal coliforms (E. coli) than permissible limit were observed in all sampling stations, indicating these sites are polluted and water at these sites were not suitable for drinking and bathing. Selected 128 fecal coli (E. coli) isolates were tested for their antibiotic sensitivity against 12 different antibiotics and results indicated out of 128 isolates screened 120 were resistant to Ampicillin, 122 isolates to Kanamycin, 92 isolates to Streptomycin and 112 isolates to Teracycline. However, most isolates were observed to be sensitive to antibiotics like Gentamycin, Chloramphenicol, Ciprofloxacin, Norfloxacin and Ofloxacin, which are commonly used in human and animal health care. The MAR indices in the range of 0.26 to 0.67 was identified in this study indicating many isolates were resistant to multiple number of antibiotics. The higher MAR levels of isolates are most probably due to the larger range of drugs utilized in human, animal and aquaculture therapy and the potential exchange of resistance during the treatment process. Considering the potential hazards of antibiotics and chemicals responsible for development of antibiotic resistant bacteria in aquatic ecosystem, use of alternative to antibiotics use like suitable antiseptics, microbial formulations and herbal medicines/preparations can be advocated for use in aquaculture operations for disease management.

\section{References}

1. Dhiman M, Dwivedi BK, Mishra SS, Tripathi RC (2014) Comparative evaluation of pollution status of river Ganga-Now and Then. Bioved 25(2): 229-242.

2. Hameed ASS, Rahaman KH, Alagan A, Yoganandhan K (2003) Antibiotic resistance in bacteria isolated from hatchery-reared larvae and postlarvae of Macrobrachium rosenbergii. Aquaculture 217(1-4): 39-48.

3. Mishra SS, Sahoo SK, Singh SK, Maurye P, Brahmane MP, et al. (2002) Assessment of microbiological quality of fish produced in sewage-fed fishery, pp. 156. The Sixth Indian Fisheries forum Abstract Dec. 17-20, 2002, ICAR- Central Institute of Fisheries Education, Mumbai, India.

4. WHO (2014) Antimicrobial resistance: global report on surveillance. WHO Library Cataloguing-in-Publication Data, World Health Organization, 20 Avenue Appia, 1211 Geneva 27, Switzerland.

5. WHO (1989) Health guideline for use of wastewater in agriculture and aquaculture. WHO Tech Rep Ser No 778. WHO, Geneva, Switzerland.

6. Mishra SS (2003) Microbial assessment of water quality for fish and health management. In: Sugunan VV, Das MK, Vinci GK, Bhoumick U (Eds.), Methods of assessment of aquatic ecosystem for fish health care, Bulletin No. 115, ICAR- Central Inland Fisheries, Research Institute, Barrackpore, Kolkata, India, pp. 145-150.

7. Mishra SS, Mali P, Dutta C, Banik HC (2007) Microbial pollution and its effect on fish, pp. 109. In: Vassudevappa C, Basavaraju Y, Seenapa D, Ayyappan S, Ravichandra Reddy S (Eds.), Proceeding of The seventh Indian Fisheries Forum, AFSIB, Mangalore, ICAR, KVAFSU, FFT(B), India, pp. 233-245.

8. APHA (2000) Standard Methods for the Examination of Water and Wastewater. $\left(10^{\text {th }}\right.$ edn), American Public Health Association. Washington, DC, USA. 
9. USFDA (2003) Bacteriological Analytical Manual. U.S. Dept. of Health and Human services. U.S. Food and Drug Administration. Centre for Food Safety \& Applied Nutrition.

10. Bauer AW, Kirby WMM, Sherris JC, Turck M (1966) Antibiotic susceptibility testing by a standardized single disc method. Am J Clin Pathol 45(4): 493-496.

11. Vivekanandhan G, Savithamani K, Hatha AAM, Lakshmanaperumalsamy $P$ (2002) Antibiotic resistance of Aeromonas hydrophila isolated from market fish and prawn of South India. Inter J Food Microbiol 76(1-2): 165-168.

12. Watkinson AJ, Micalizzi GB, Graham GM, Bates JB, Costanzo SD (2007) Antibiotic-Resistant Escherichia coli in Wastewaters, Surface Waters, and Oysters from an Urban Riverine System. Appl Environ Microbiol 73(17): 5667-5670.

13. Krumperman PH (1985) Multiple antibiotic indexing of E. coli to identify high-risk sources of fecal contamination of foods. Appl Environ Microbiol 46(1): 165-170.

14. Ali MR, Al-Alak SK, Hassan AS (2014) Antibiogram typing and ERICPCR genotyping of Escherichia coli isolated from different clinical samples. World J of Pharmacy and Pharmaceutical Sciences 3(7): $27-$ 37.

15. Ram S, Vajpayee P, Tripathi U, Singh RL, Seth PK, et al. (2008) Determination of antimicrobial resistance and virulence gene signatures in surface water isolates of Escherichia coli. Journal of Applied Microbiology 105: 1899-1908.

16. Dhaka P, Vijay D, Vergis J, Negi M Kumar, Mohan M, et al. (2016) Genetic diversity and antibiogram profile of diarrhoeagenic Escherichia coli pathotypes isolated from human, animal, foods and associated environmental sources. Infect Ecol Epidemiol 6(1): 31055.

17. Radu Son, Ahmad Noorlis, Ling Foo Hooi, Reezal Abdul (2003) Prevalence and resistance to antibiotics for Aeromonas species from

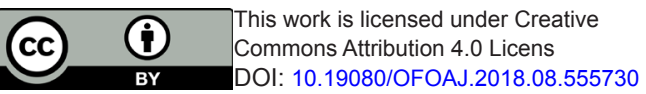

retail fish in Malaysia. International Journal of Food Microbiology 81(3): 261-266.

18. Abraham TJ, Manley R, Palaniappan R, Dhevendran K (1997) Pathogenicity and antibiotic sensitivity of luminous Vibrio harveyi isolates from diseased penaeid shrimp. J Aqua Trop 12(1): 1-8.

19. Thakur AB, Vaidya RB, Suryawanshi SA (2003) Pathogenicity and antibiotic susceptibility of Vibrio species isolated from moribund shrimps. Indian J Mar Sci 32(1): 71-75.

20. Mishra SS, Dhiman Mitali, Das Priyanka Dutta C, Mali P, Samanta S (2010) Antimicrobial sensitivity of bacterial flora associated with septicaemic vibriosis in tiger shrimp, Penaeus monodon. Journal of Inland Fisheries Soc of India 42(1): 78-83.

21. Sasmal D, Abraham TJ (2004) Antibiotic sensitivity of bacterial flora associated with diseasedprawn Macrobrachium rosenbergii. J Inland Fish Soc India 36(2): 68-70.

22. Hameed ASS, Rao PV (1994) Studies on the chemical control of a Vibrio campbelli-like bacterium affecting hatchery reared Penaeus indicus larvae. Aquaculture 127(1): 1-9.

23. Nontongana N, Timothy S, Elvis N, Anthony I Okoh (2014) Prevalence and Antibiogram Profiling of Escherichia coli Pathotypes Isolated from the Kat River and the Fort Beaufort Abstraction Water. Int J Environ Res Public Health 11(8): 8213-8227.

24. Kinge NW, Ateba CN, Kawadza DT (2010) Antibiotic resistance profiles of Escherichia coli isolated from different water sources in the Mmabatho locality, North-West province, South Africa. S Afr J Sci 106(1-2): 44-49.

25. FDA (1986) Aquaculture drug notice by USFDA. U.S. Food and Drug Administration, Aquacult Mag 12(4): 4-5.

26.USFDA (2017) Approved Aquaculture Drugs. US Food and Drug Administration, USA.

\section{Your next submission with Juniper Publishers will reach you the below assets}

- Quality Editorial service

- Swift Peer Review

- Reprints availability

- E-prints Service

- Manuscript Podcast for convenient understanding

- Global attainment for your research

- Manuscript accessibility in different formats

( Pdf, E-pub, Full Text, Audio)

- Unceasing customer service

Track the below URL for one-step submission https://juniperpublishers.com/online-submission.php 